\title{
Understanding the somatic consequences of depression: biological mechanisms and the role of depression symptom profile
}

\author{
Brenda WJH Penninx ${ }^{1,3^{*}}$, Yuri Milaneschi ${ }^{1}$, Femke Lamers ${ }^{2}$ and Nicole Vogelzangs ${ }^{1}$
}

\begin{abstract}
Depression is the most common psychiatric disorder worldwide. The burden of disease for depression goes beyond functioning and quality of life and extends to somatic health. Depression has been shown to subsequently increase the risk of, for example, cardiovascular, stroke, diabetes and obesity morbidity. These somatic consequences could partly be due to metabolic, immuno-inflammatory, autonomic and hypothalamic-pituitary-adrenal (HPA)-axis dysregulations which have been suggested to be more often present among depressed patients. Evidence linking depression to metabolic syndrome abnormalities indicates that depression is especially associated with its obesityrelated components (for example, abdominal obesity and dyslipidemia). In addition, systemic inflammation and hyperactivity of the HPA-axis have been consistently observed among depressed patients. Slightly less consistent observations are for autonomic dysregulation among depressed patients. The heterogeneity of the depression concept seems to play a differentiating role: metabolic syndrome and inflammation up-regulations appear more specific to the atypical depression subtype, whereas hypercortisolemia appears more specific for melancholic depression. This review finishes with potential treatment implications for the downward spiral in which different depressive symptom profiles and biological dysregulations may impact on each other and interact with somatic health decline.
\end{abstract}

Keywords: Depression, Metabolic syndrome, Inflammation, Cortisol, Autonomic Tone, Cardiovascular, Obesity, Symptom profile, Treatment

\section{Review}

Introduction

Depressive feelings are a normal component of distress or grief. When depressive feelings turn into a chronic, disabling disorder interfering with daily life, a clinical diagnosis of major depressive disorder (MDD or shortly termed depression) ensues. Depression refers to a range of mental problems characterized by loss of interest and enjoyment in ordinary experiences, low mood and associated emotional, cognitive, physical and behavioral symptoms. Depression is one of the most prevalent diseases globally: $6 \%$ of the population meets the MDD criteria at a specific time point. During a lifetime, depression affects

\footnotetext{
*Correspondence: b.penninx@vumc.nl

'Department of Psychiatry, EMGO+ Institute and Neuroscience Campus Amsterdam, VU University Medical Center, Amsterdam, The Netherlands ${ }^{3}$ Department of Psychiatry, VU University Medical Center and GGZinGeest, AJ Ernststraat 1187, 1081 HL, Amsterdam, The Netherlands

Full list of author information is available at the end of the article
}

one out of every six adults with women being affected twice as often as men [1]. Currently, depression is the third leading contributor to the global disease burden, but will rise to a first-place ranking by 2030 [2]. This is largely due to the facts that depression is common, has a major impact on functioning and quality of life, and affects persons often in early life and for sustained periods, thereby causing many disease years. Consequently, depression largely affects public health and involves high societal costs.

\section{Somatic consequences of depression}

The impact of depression on health extends beyond quality of life and functioning outcomes. Over the last 20 years, many studies illustrated the impact of depression on incident somatic disease development. Table 1 summarizes meta-analyses integrating evidence from longitudinal studies conducted among initially disease-

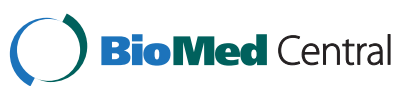


Table 1 Meta-analyses examining the association between depression and incidence of mortality or morbidity in disease-free subjects

\begin{tabular}{lllll}
\hline Incident event & Reference & Nr studies included & Nr subjects included & Pooled risk (95\% Cl) of depression \\
\hline Overall mortality & Cuijpers et al. [5] & 25 & 106,628 & 1.81 (1.58 to 2.07) \\
Heart disease & Nicholson et al. [3] & 21 & 124,509 & $1.81(1.53$ to 2.15) \\
Hypertension & Meng et al. [12] & 9 & 22,367 & $1.42(1.09$ to 1.86) \\
Stroke & Dong et al. [13] & 17 & 206,641 & $1.34(1.17$ to 1.54$)$ \\
Diabetes & Mezuk et al. [4] & 13 & 212,019 & $1.60(1.37$ to 1.88$)$ \\
Alzheimer's disease & Gao et al. [14] & 4 & 5,656 & $1.66(1.29$ to 2.14$)$ \\
Obesity (BMI $\geq 30)$ & Luppino et al. [15] & 9 & 6,436 & $1.58(1.33$ to 1.81$)$ \\
Cancer & Chida et al. [16] & 25 & n.a. & $1.29(1.14$ to 1.46)
\end{tabular}

BMI, Body mass index; $\mathrm{Cl}$, Confidence interval; n.a., Not available.

free subjects. These meta-analyses consistently show that depression increases the risk of overall mortality $(\mathrm{RR}=1.81)$ and the development of cardiovascularrelated outcomes, such as heart disease $(R R=1.81)$, diabetes $(R R=1.60)$, hypertension $(R R=1.42)$, stroke $(\mathrm{R} R=1.34)$ and obesity $(\mathrm{RR}=1.58)$. Meta-analyses also indicate that depression increases the risk of developing Alzheimer's disease $(R R=1.66)$ and to a lesser extent even cancer $(R R=1.29)$. Most meta-analyses have been based on longitudinal studies using depressive symptom checklists which pick up many subthreshold depression cases. However, the increased somatic morbidity has also been found in patients fulfilling psychiatric diagnostic criteria, who - in line with a dose-response association have slightly higher incident morbidity rates [3-5]. The observed increased somatic risks associated with depression are substantial. For instance, the $81 \%$ increased risk for cardiovascular disease onset is very similar to that observed for well-established risk factors, such as obesity [6], metabolic syndrome [7], low high-density lipoprotein (HDL) cholesterol [8] or high C-reactive protein (CRP) [9]. Recently, the Global Burden of Disease project listed depression as one of the main contributors to disability ( $2^{\text {nd }}$ rank [10]) and diminished active life expectancy $\left(11^{\text {th }}\right.$ rank [11]). If one would have been able to take the negative impact of depression on somatic morbidity into consideration, the estimated negative contribution of depression to public health would be even larger.

Meta-analyses on somatic consequences of depression have reported pooled effect sizes for adjusted associations which considered potential confounding variables such as lifestyle indicators. Depressed persons are on average unhealthier; they are more likely to smoke, drink excessive amounts of alcohol, eat an unhealthy diet and be more physically inactive than non-depressed peers [17]. Many - but not all - of the conducted studies associating depression to incident medical morbidity have tried to adjust for life style differences. These lifestyle adjusted pooled effect sizes are only slightly lower than unadjusted ones, suggesting that the increased morbidity risks are not simply due to lifestyle differences. However, considering the fact that, for example, nutritional and physical activity patterns are not easy to assess in detail in large-scale observational studies, residual impact of these behavioral factors may still exist. In addition, poorer self-care and poorer compliance with general health regimens have been reported among depressed persons [18] and may add to the found link between depression and somatic disease development. Alternative explanations for the link between depression and increased morbidity development could be underlying factors that explain both outcomes rather independently, such as low socio-economic status, childhood maltreatment or shared genetic effects (genetic pleiotropy).

In addition to the above provided explanations, depression-related biological dysregulations that also constitute risk factors for somatic illnesses could further contribute to the observed depression and somatic disease link. The next section describes evidence for biological dysregulations examined in this context. It should be emphasized that within the realm of this paper we are not able to delineate in much detail all potential underlying biological dysregulations linking depression to somatic illnesses. We focused on the most commonly examined biological dysregulations in this respect, namely metabolic, immuno-inflammatory, autonomic and hypothalamic-pituitary-adrenal (HPA)-axis dysregulations.

\section{Biological dysregulation linking depression to somatic health \\ Metabolic dysregulation}

Often clinical metabolic dysregulations are assessed in the context of the metabolic syndrome: a cluster of general metabolic risk factors including abdominal obesity, increased blood glucose (hyperglycemia), elevated blood pressure, increased triglycerides and decreased HDL cholesterol. Metabolic dysregulations are well-established risk factors for the development of various somatic conditions, including, for example, cardiovascular disease, diabetes, 
obesity, cognitive impairment and even cancer [7,19-21], thereby being a potential linking mechanism between depression and incident somatic conditions. Pan et al. [22] systematically reviewed 29 cross-sectional studies and found depression and the metabolic syndrome to be modestly associated (unadjusted $\mathrm{OR}=1.42$; adjusted $\mathrm{OR}=$ 1.34). Some reviewed prospective studies confirmed a bidirectional association with depression predicting the onset of metabolic syndrome, which in turn predicted depression onset over time. However, the metabolic syndrome is a heterogeneous concept: pathophysiological mechanisms of elevated blood pressure, dyslipidemia and hyperglycemia are not necessarily similar. Therefore, various studies have tested consistency of associations with depression across different metabolic syndrome components. The most consistent evidence exists for depression and obesity-related components (abdominal obesity, low HDL cholesterol, hypertriglyceridemia) [23-52]. Depression associations with hyperglycemia [25,27,28,37,39,41-47,50] and hypertension were less often confirmed [28,32,47,53-56]. Also when evidence from longitudinal studies was pooled, consistent associations were only confirmed for the obesity-related components [22]. This is in line with a recent metaanalysis [57] which showed that abdominally obese persons are at a 1.38 increased odds of having depression (Table 2). One longitudinal study among depressed patients found that a combination of multiple metabolic dysregulations contributed to chronicity of depression [33]. Taken together, literature suggests that abdominal obesity and lipid disturbances are the driving force behind the relationship between depression and metabolic syndrome. Once both are present, abdominal obesity might give rise to multiple metabolic dysregulations, which in turn might be responsible for remaining in a depressed state.

How could a link between metabolic dysregulation and depression be explained? White adipose tissue,

Table 2 Overview of meta-analyses examining the cross-sectional association between biological dysregulations and depression status

\begin{tabular}{|c|c|c|c|c|}
\hline & Reference & $\mathrm{Nr}$ studies included & Nr subjects included & Pooled effect size $(95 \% \mathrm{Cl})$ \\
\hline \multicolumn{5}{|l|}{ Metabolic dysregulation } \\
\hline Metabolic syndrome & Pan et al. 2012 [22] & 29 & 155,333 & $\mathrm{OR}=1.42(1.28$ to 1.57$)$ \\
\hline Abdominal obesity & Xu et al. $2011^{1}$ [57] & 15 & 34,832 & $\mathrm{OR}=1.38(1.22$ to 1.57$)$ \\
\hline \multicolumn{5}{|c|}{ Immuno-inflammatory dysregulation } \\
\hline C-Reactive Protein & Howren et al. 2009' [58] & 49 & 51,234 & $d=0.15(0.10$ to 0.21$)$ \\
\hline Interleukin-6 & & 61 & 24,837 & $d=0.25(0.18$ to 0.31$)$ \\
\hline Interleukin-1 $\beta$ & & 14 & 756 & $d=0.35$ (0.03 to 0.67$)$ \\
\hline Interleukin-1RA & & 9 & 1,214 & $d=0.25(0.04$ to 0.46$)$ \\
\hline Interleukin-6 & Dowlati et al. $2010^{2}$ [59] & 16 & 892 & $\mathrm{MD}=1.8 \mathrm{pg} / \mathrm{mL}$ (1.2 to 2.3$)$ \\
\hline TNF-a & & 13 & 788 & $\mathrm{MD}=4.0 \mathrm{pg} / \mathrm{mL}$ (2.2 to 5.7$)$ \\
\hline Interleukin-1 $\beta$ & & 9 & 533 & $\mathrm{MD}=-1.6 \mathrm{pg} / \mathrm{mL}(-3.6$ to 0.4$)$ \\
\hline Soluble Interleukin-2R & Liu et al. $2012^{2}$ [60] & 8 & 596 & $\mathrm{MD}=0.56 \mathrm{pg} / \mathrm{mL}$ (0.28 to 0.84$)$ \\
\hline Interleukin-6 & & 18 & 923 & $\mathrm{MD}=0.68 \mathrm{pg} / \mathrm{mL}$ (0.44 to 0.92$)$ \\
\hline TNF-a & & 15 & 995 & $\mathrm{MD}=0.55 \mathrm{pg} / \mathrm{mL}$ (0.13 to 0.99$)$ \\
\hline Interleukin-1ß & & 10 & 580 & $\mathrm{MD}=-0.53 \mathrm{pg} / \mathrm{mL}(-1.36$ to 0.31$)$ \\
\hline \multicolumn{5}{|l|}{ Autonomic dysregulation } \\
\hline Heart rate variability & Rottenberg, $2007^{2}[61]$ & 13 & 686 & $d=0.33(0.18$ to 0.49$)$ \\
\hline Heart rate variability & Kemp et al. $2010^{2}$ [62] & 14 & 726 & Hedges' $g=-0.21(-0.40 \text { to }-0.02)^{4}$ \\
\hline \multicolumn{5}{|l|}{ HPA-axis dysregulation } \\
\hline Higher cortisol ${ }^{3}$ & Stetler and Miller 2011 [63] & 354 & 18,374 & $d=0.60(0.54$ to 0.66$)$ \\
\hline Higher ACTH & & 96 & 3,812 & $d=0.28(0.16$ to 0.41$)$ \\
\hline Higher CRH & & 16 & 888 & $d=-0.53(-1.71$ to 0.65$)$ \\
\hline Saliva morning cortisol & Knorr et al. 2010' [64] & 20 & 2,318 & $\mathrm{MD}=2.6 \mathrm{nmol} / \mathrm{l}(1.0$ to 4.2$)$ \\
\hline Saliva evening cortisol & & 10 & 1,617 & $\mathrm{MD}=0.3 \mathrm{nmol} / \mathrm{l}(0.03$ to 0.5$)$ \\
\hline
\end{tabular}

$\mathrm{ACTH}$, Adrenocorticotropin hormone; Cl, Confidence interval; $\mathrm{CRH}$, Corticotropin-releasing hormone; d, Cohen's d; HPA, hypothalamic-pituitary-adrenal; MD, Mean difference between depressed and non-depressed; OR, Odds ratio; TNF, Tumor necrosis factor.

1 Included depressed cases based on self-report checklists or psychiatric diagnostic criteria.

2 Only included depressed cases conform to psychiatric diagnostic criteria.

3 Cumulative assessment of cortisol across body fluids and across various time points.

4 Did not include data from one study including 1,018 depression patients and 515 controls that found a much smaller effect size (d $=0.12$ ). 
especially in the abdominal area, is an active endocrine organ producing inflammatory cytokines and hormones (for example, leptin) and, therefore, a major contributor to pathogenic immunometabolic responses linked to metabolic diseases and depression. For instance, inflammatory factors stimulate the release of lipids in the bloodstream to provide energy for host defense and cause a reduction in HDL cholesterol [65]. Moreover, obesity-related chronic inflammation is involved in the development of insulin resistance through activation of the inhibitor of $k B$ kinase- $\beta /$ nuclear factor- $k \beta$ (IKK $\beta$ / NFk $\beta$ ) complex [66]. Leptin is an anti-obesity hormone regulating nutritional intake and energy expenditure. In the central nervous system obesity-associated inflammation can disrupt leptin hypothalamic action through IKK $\beta / N F k \beta$ regulation of SOCS-3 (suppressor of cytokine signaling-3), a key inhibitor of leptin signaling [67]. The resulting state of leptin central resistance, characterized by the failure of high levels of leptin to suppress food intake and decrease adiposity, is a hypothesized shared biological mechanism underlying obesity and depression. Leptin receptors are expressed in limbic substrates related to mood regulation, and in animal models leptin exerts antidepressant behavioral effects [68]. Leptin has also been shown to affect hippocampal and cortical structure through its actions on neurogenesis, axon growth, synaptogensis and dendritic morphology regulation [69].

Another possible mechanism linking metabolic dysregulation and depression may be represented by cerebrovascular damage associated with metabolic syndrome, which have been hypothesized to predispose people to depression, especially in late-life [70]. Finally, other depression-related biological dysregulations described in this review may constitute shared underlying pathways to metabolic alterations. For instance, adipose tissue expresses a high density of glucocorticoid receptors, and their binding with cortisol activates lipoprotein lipase and inhibits lipid mobilization, leading to an accumulation of triglycerides [71]. Similarly, sympathetic nervous system overactivation is connected to high blood pressure [72].

\section{Immuno-inflammatory dysregulation}

A consistent body of evidence indicates that depression is associated with dysregulated inflammation, an immune response that derives from activation of the innate immune system. The inflammatory mediators' network is represented by a bewildering array of molecules, the most prominent of which are proinflammatory cytokines (for example, interleukin (IL)-1, IL-6 and tumor necrosis factor (TNF)- $\alpha$ ) produced within innate immune cells in response to immunologic challenge. Other cytokines, known as anti-inflammatory, oppose this response by attenuating the production of proinflammatory cytokines (for example, IL-10) or by antagonizing their action at the receptor level (for example, IL-1RA). In turn, the actions of proinflammatory cytokines on peripheral cellular targets, such as hepatocytes, lead to the synthesis of acute phase proteins (for example, CRP) responsible for the systemic inflammatory response. The link between depression and inflammation was initially suggested by clinical findings showing that depression is accompanied by up-regulated inflammatory response, such as an increased production of pro-inflammatory cytokines and acute phase reactive proteins $[73,74]$. Systemic elevations of these molecules in the absence of infection or tissue injury are considered abnormal and increase the onset of, for example, cardiovascular disease, diabetes and mortality [75,76]. There is a strong interconnection between metabolic abnormalities and inflammation illustrated by the facts that abdominal fat tissue produces cytokines and these, subsequently, increase metabolic syndrome development $[77,78]$.

Three recent meta-analyses reported significantly higher levels of the inflammatory markers TNF- $\alpha$, sIL-2R, IL-6 and IL-1RA in depressed subjects compared to controls (see Table 2). Dowlati et al. [59] confirmed increased levels of IL- 6 and TNF- $\alpha$ among drug-naive MDD patients. Liu et al. [60] recently extended this evidence to sIL-2R. For IL-1 $\beta$, no consistent significant association was found in both meta-analyses [59,60]. Howren et al. [58] confirmed the depression-inflammation association also in larger population samples, many of which used depressive symptom reports and most often studied IL-6 and CRP, a nonspecific acute-phase protein synthesized in the liver in response to cytokine stimulation. They confirmed stronger associations - although still of modest effect size - with inflammatory markers for studies using clinical diagnoses of depression than those using symptom reports. An essential role was found for body mass index (BMI) as a covariate: studies adjusting for BMI found much lower effect sizes, likely due to the fact that adipose tissue is an important source of cytokines. However, even after adjustment for BMI, elevated inflammation levels in the depressed were observed, indicating that immune and metabolic dysregulations are partly complementary.

Most meta-analyzed studies were cross-sectional, which makes it hard to draw any causal inferences. However, several lines of research indicate that the link between inflammation and depression is likely bidirectional [79]. It has been demonstrated that immunotherapy with IFN- $\alpha$ can precipitate depression [80]. Cytokines produced peripherally can access the brain directly by crossing the blood-brain barrier through saturable active transport systems, or via indirect pathways including activation of microglia, diffusion into the brain through leukocytes in the choroid plexus and circumventricular region, and 
attraction in the brain of monocytes by chemo-attractant proteins released by microglia [81]. Activated microglia employ IL- 6 and TNF- $\alpha$ as antineurogenic signals, which can interact directly with neural progenitor cells via TNF and IL-6 receptors causing a decrease in neurogenesis, and also in emotion-regulating brain structures involved in depression.

Another mechanism relating pro-inflammatory cytokines to mood is their capacity to induce the indoleamine2,3-dioxygenase (IDO) enzyme, which catalyzes the synthesis of kynurenine from dietary tryptophan [82]. This may contribute to depressive symptoms by reducing the availability of the requisite precursor (tryptophan depletion) for the synthesis of serotonin and melatonin. Perhaps even more importantly, IDO activation also increases the synthesis of tryptophan catabolites (TRYCATs), such as kynurenine, kynurenic acid and quinolinic acid. The latter is an endogenous $\mathrm{N}$-methyl-D-aspartate agonist that could perturb neurotransmission along glutamatergic pathways and may lead to hippocampal neuron damage and apoptosis which could contribute to depression symptoms [83]. Some - but not all - studies confirmed higher TRYCAT levels in depressed patients, especially those depressed cases with physio-somatic symptoms [84] and TRYCAT levels have been linked with cardiac dysfunction, pain and other somatic health complaints (see Anderson G et al. [85] for more detailed description).

Recent findings from clinical studies suggest that depression is also associated with other immune-related mechanisms, such as cell-mediated immunity and autoimmune responses directed against cell structures altered by oxidative and nitrosative stress. A detailed discussion of these aspects goes beyond the scope of this review, but has been recently summarized $[81,86,87]$.

Pro-inflammatory cytokines have been shown to induce stress-reactive neuroendocrine and central neurotransmitter changes reminiscent of those in depression [79]. Inflammatory processes can influence central serotonin availability also through increased uptake after phosphorylation of the high-affinity serotonin transporter via the activation of p38 mitogen-activated protein kinases [81]. Finally, as discussed above, fat mass and its associated metabolic regulations are strongly connected to inflammation. Nutrition overload causes adipocytes to become hypertrophic and to secrete chemo-attractant proteins, which lead to recruitment of macrophages that produce their own pro-inflammatory cytokines and chemokines, attracting additional macrophages and setting up a feed-forward inflammatory process [66]. Depression may also facilitate weight gain partly as a result of sedentary behavior and unhealthy dietary choice - which in turn promotes inflammation that may ultimately reinforce depression, creating a deleterious vicious cycle for physical and mental health.

\section{Autonomic dysregulation}

Acute stress results in immediate activation of sympathetic nerves and reduction of parasympathetic nerves in order to prepare the body for a fight or flight response. An indication of autonomic activity can be obtained from looking at catecholamine levels. Indeed, some older studies indicate a tendency for the urinary excretion of noradrenaline and its metabolites to be diminished $[88,89]$, whereas other reports document elevated plasma levels of noradrenaline [90]. A more direct way of measuring autonomic tone is by measuring noradrenaline spillover to plasma $[91,92]$ in patients with MDD. A recent noradrenaline spillover study among MDD patients by Barton et al. [93] found sympathetic nervous activity to be high, including the sympathetic outflow to the heart, but this was restricted to only a subgroup of MDD patients.

Such invasive spillover studies are unfortunately not easily implementable in large psychiatric cohorts, restricting our insights into generalizability of results and the role of potential underlying confounding factors. That is why many researchers have used non-invasive, but more indirect indicators of autonomic tone, for example, obtained from electrical and impedance cardiography assessments. A non-invasive method for autonomic dysregulation assessment is heart rate variability (HRV), particularly in the respiratory frequency range, as an indicator of cardiac vagal control. HRV reflects an individual's capacity for parasympathetic inhibition of autonomic arousal in emotional expression and regulation, and is an important predictor for cardiovascular disease and mortality [94,95]. Depression is hypothesized to involve an autonomic nervous system that is in a relative state of more sympathetic and less parasympathetic activation. According to the polyvagal theory, this is partly due to the fact that impairments of low vagal tone are associated with reduced social engagement and a less flexible behavioral response to environmental changes [96].

Rottenberg [61] summarized 13 studies including 312 depressed patients and 374 controls and found a significantly reduced HRV in depression (Cohen's $d=0.33$, see Table 2). Four years later, Kemp et al. [62] repeated a meta-analysis in which only power-domain analyses were allowed to measure HRV and all included subjects were free of cardiovascular disease. Meta-analyzing results of 14 studies (302 patients, 424 controls) yielded a significant pooled effect size indicating a lower HRV among the depressed. Contrary to these results, was a study by Licht et al. [97] with a sample size that was by far larger than the total number of participants in the meta-analyses, and could adjust for lifestyle. In this study, 1,018 MDD patients without antidepressants and 515 controls did not consistently show differences in HRV on all measures. Only on the respiratory sinus arrhythmia indicator of HRV the depressed persons 
scored slightly lower with a small effect size of 0.12 . In their two-year follow-up [98] it was confirmed that MDD state (changes) were not associated with HRV. On the contrary, significantly lower HRV was found among MDD patients using antidepressant medication, especially tricyclic antidepressants (TCAs) and serotonergicnoradrenergic reuptake inhibitors (SNRIs). This led to the authors' conclusion that it is not the depressed state but the use of antidepressants that changes autonomic tone. The TCA effect on HRV, likely through direct anticholinergic effects, was recently confirmed in a metaanalysis [62]. So it remains rather unclear whether depression itself is associated with a reduced vagal tone. Of note is that studies included in these meta-analyses measured an autonomic tone during resting conditions. Depression could be more strongly associated with reduced parasympathetic tone when persons are exposed to stress conditions.

Sympathetic tone in depressed persons has been less often examined on a large scale, and no meta-analysis is available. Some small-scale studies reported increased sympathetic activity in depressed subjects measured indirectly by skin conductance responses, QT interval variability or the pre-ejection period (PEP) [91,99-102], although not consistently [103]. In contrast to invasive norepinephrine spillover studies, the advantage of assessing PEP, a thoracic impedance cardiography measure indexing changes in $\beta$-adrenergic inotropic drive to the left ventricle, is that it can be obtained noninvasively in large samples, thereby allowing greater generalizability of results, and examination of potential confounding factors. However, it should be noted that PEP is an indirect sympathetic tone indicator since it may also be influenced by changes in clearance, reuptake or adrenoceptor sensitivity. A recent large study compared PEP among 1,093 MDD patients and 621 controls [104]. Cross-sectional nor two-year longitudinal results could confirm a higher sympathetic tone in the depressed. Again, antidepressant medication, especially TCAs and to a lesser extent SNRIs, was associated with increased sympathetic tone.

Overall, although some evidence points towards a hypersympathetic/hypovagal state among depressed persons, the evidence is not consistent and antidepressant treatment appears to be a strong confounding factor. Autonomic dysregulation is involved in cardiovascular somatic symptoms, such as tachycardia, blood pressure liability and tendencies toward hypertension. In a large cohort study [105], lower HRV was associated with more metabolic syndrome dysregulations, but not to HPA-axis activity. Finally, sympathetic activation may have a role in the stress-induced activation of the immune system as catecholamines can trigger the inflammatory signaling cascade [106].

\section{Hypothalamic-pituitary-adrenal (HPA) axis dysregulation}

Hyperactivity of the HPA-axis in depression has been considered one of the most reliable findings in biological psychiatry. Chronic stress is perceived by the cortex of the brain and transmitted to the hypothalamus, where corticotropin-releasing hormone $(\mathrm{CRH})$ is released onto pituitary receptors, ultimately resulting in release of cortisol into the blood [107]. To assess HPA-axis activity, salivary measures are increasingly used to reflect the active unbound form of cortisol. The cortisol awakening response assesses the natural response of the HPA-axis to awakening; evening cortisol levels reflect basal activity. Knorr et al. [64] meta-analyzed 20 case-control studies including 1,354 depressed patients and 1,052 controls (Table 2). The average salivary cortisol level was $2.58 \mathrm{nmol} / \mathrm{l}$ increased in the morning and $0.27 \mathrm{nmol} / \mathrm{l}$ in the evening for depressed patients. A recent study among 701 current and 579 remitted depressed cases found that both groups had higher cortisol awakening response and evening levels as compared to 308 healthy controls [108], suggesting that HPA-axis hyperactivity represents more a vulnerability than a state indicator. In line with this, HPA-axis hyperactivity has also been observed among non-affected offspring of depressed patients, suggesting that it may partly reflect a genetic vulnerability marker or endophenotype of depression [109].

In an even larger meta-analysis by Stetler and Miller [63], evidence for higher cortisol levels across various bodily fluids was summarized. Again, this evidence illustrated that depressed individuals displayed increased cortisol levels $(\mathrm{d}=0.60)$, although the effect size was considerably less - and only modest when only high methodological quality studies were included $(\mathrm{d}=0.33)$. Effect sizes were higher for cortisol levels determined in plasma or urine than for those in saliva. The authors also meta-analyzed other HPA-axis indicators and found elevated levels of adrenocorticotropin hormone (ACTH) among the depressed $(\mathrm{d}=0.28)$, but no elevation in $\mathrm{CRH}(\mathrm{d}=0.02)$.

Some studies used a dexamethasone test to evaluate the sensitivity of the hypothalamus to feedback signals for the shutdown of CRH release. No meta-analysis has compared dexamethasone suppression across regular depressed cases and controls. Nelson et al. [110] described that dexamethasone-suppression studies found that the normal cortisol-suppression response is absent in about half of the patients with very severe symptoms (for example, those hospitalized or those with psychotic symptoms). The non-suppression rate in outpatients with major depression was found to be much lower. A recent large-scale study did not find a different cortisol response after dexamethasone $(0.5 \mathrm{mg})$ suppression in 1,280 MDD outpatients versus controls [108]. So, the indicated larger non-suppression of the HPA-axis in 
depression is likely restricted to only the most severe (psychotic) cases.

Several mechanisms may underlie the relationship between HPA-axis dysregulation and depression. Although hypercortisolism may be related to alterations at any level of the HPA-axis, research in depression focused on the role of mineralocorticoid (MR) and glucocorticoid (GR) receptors, acting as transcriptional regulators of cortisol effects on the initiation and termination of the stress response [111]. Both types of receptor are abundantly expressed in neurons of limbic regions but have different affinity to cortisol (approximately 10-fold higher for MR that is heavily occupied by basal glucocorticoids levels, while GR is only heavily occupied during stress) and different transcriptional activity. MR is implicated in the appraisal process that triggers the stress response, while GR is part of a negative feedback aimed at normalizing HPA-axis output. Alterations of this regulating network, defined glucocorticoid resistance, may determine a chronic activation of the stress response resulting in atrophy of hippocampal cells, reduced neurogenesis and synaptic plasticity and altered monoaminergic signaling, all of which may lead to a depressive state [111]. Other factors may be involved in the dysregulation of HPA-axis responsiveness, including early-life epigenetic programming of GR genes and inflammatory processes [112]. A wide range of studies showed that pro-inflammatory cytokines may promote the release of $\mathrm{CRH}, \mathrm{ACTH}$ and cortisol by acting directly on hypothalamic and pituitary cells and disrupting GR function leading to glucocorticoid resistance $[112,113]$.

\section{Heterogeneity of depression: the role of symptom profiles}

All meta-analyses described in Table 2 indicated in general a modest effect size and a considerable amount of heterogeneity in biological dysregulations among depressed persons. Such variability could be attributable to sampling (for example, clinical sample vs. community), sample composition (for example, age and ethnic composition) or methodological differences in depression and biological measures. However, variability could also be due to heterogeneity of depression. There is general consensus that clinical heterogeneity hinders efforts to identify biologic, genetic and environmental underpinnings of depression. In fact, the lack of genetic markers associated with MDD in the largest collaborative genetic study was interpreted to be largely attributable to its widespread heterogeneity [114]. It is crucial that depressive subtypes constituting more homogeneous phenotypes are taken into account in research and that in-depth studies of biological correlates of depressive subtypes are conducted in order to bring the psychiatric field forward.
The current Diagnostic and Statistical Manual of Mental Disorders (DSM) classification includes three specifiers of symptom characteristics during depressive episodes: catatonic, melancholic and atypical features. Most outpatient and community studies focus on melancholic and atypical subtypes because of the low frequency of catatonia. Atypical depression is marked by hypersomnia and fatigue, increased appetite and weight gain, mood reactivity and interpersonal rejection sensitivity. Unlike its name suggests, it is present in approximately $15 \%$ to $30 \%$ of depressed cases $[115,116]$. Melancholic depression is characterized by a disturbance in affect marked by anhedonia and non-reactive mood, by psychomotor disturbance and by vegetative and cognitive symptoms of insomnia, loss of appetite and weight, diurnal mood variation and impaired concentration. Approximately 25 to $30 \%$ of depressed individuals display melancholic features [115]. Criteria for subtypes were originally established based on clinical observations, but it should be noted that not all core criteria of these subtype definitions have been justified through research. In fact, some of the core characteristics of the atypical subtype have received increased scrutiny by research showing that the cardinal symptom of mood reactivity is not associated with the other subtype symptoms $[117,118]$, and the interpersonal rejection sensitivity may be more a personality trait than a symptom [119]. Nevertheless, recent data-driven techniques examining a wide range of depressive symptoms have confirmed that depressed populations can generally be divided into a melancholic (sometimes termed 'typical') and an atypical subtype which are not very different in overall severity but differentiate mainly in terms of appetite, weight and sleep symptoms (more in atypical, less in melancholic depression) $[115,116,120-122]$ and to a lesser extent in terms of feelings of worthlessness, guilt and suicidal ideation (more in melancholic depression) [115]. Distinction in these subtypes is rather stable over time, as pointed out in a recent longitudinal study among chronic patients [116]; of persons with atypical depression at baseline, $79 \%$ still had the atypical subtype after two years, which was $70 \%$ in those with melancholic depression.

Increasing evidence suggests that melancholic and atypical depressive subtypes contribute to variability in associations with biological measures. Table 3 lists studies examining this issue. Comparing melancholic depressed versus nonmelancholic depressed persons, Seppälä et al. [53] found metabolic syndrome to be increased in those with atypical depression but not in melancholic depression. In line with this, when directly comparing 319 melancholic versus 201 atypical depressed patients, Lamers et al. [115] found metabolic syndrome and, in particular, its obesity-related disturbances to be more present in atypical depression. 
Table 3 Overview of studies comparing biological dysregulations across melancholic and atypical depression

\begin{tabular}{|c|c|c|c|c|}
\hline Reference & $\begin{array}{l}\text { Nr of melancholic } \\
\text { depression }\end{array}$ & $\begin{array}{l}\text { Nr of atypical } \\
\text { depression }\end{array}$ & $\begin{array}{l}\mathrm{Nr} \text { of } \\
\text { controls }\end{array}$ & Summary of findings \\
\hline \multicolumn{5}{|l|}{ Metabolic dysregulation } \\
\hline Lamers et al. 2010 [115] & 379 & 201 & - & $\mathrm{AD}$ more MetS than MD \\
\hline Seppala et al. 2012 [53] & 293 & $139^{1}$ & 2,388 & AD more MetS than $C$, no association with $M D$ \\
\hline \multicolumn{5}{|c|}{ Immuno-inflammatory dysregulation } \\
\hline Anisman et al. 1999 [123] & 17 & 31 & 27 & No difference in IL-1b + IL-2 \\
\hline Kaestner et al. 2005 [124] & 21 & $16^{1}$ & 37 & $A D$ higher IL-1b + IL-1RA than $C+M D$ \\
\hline Huang et al. 2007 [125] & 25 & $17^{1}$ & 40 & $\begin{array}{l}\text { MD higher IL-1b than AD no difference in IL-10 and } \\
\text { TNF- } a\end{array}$ \\
\hline Yoon et al. 2012 [126] & 70 & 35 & - & $\begin{array}{l}\text { AD higher IL-2 and lower IL-4 than MD no differences } \\
\text { in IL- } 6+\text { TNF- } a\end{array}$ \\
\hline Lamers et al. 2012 [127] & 111 & 122 & 543 & AD higher IL-6 + CRP + TNF- $a$ than MD $+C$ \\
\hline Karlovic et al. 2012 [128] & 32 & 23 & 18 & $\begin{array}{l}\text { MD + AD higher IL- } 6+\text { CRP than } C \text { no difference in } \\
\text { TNF- } a\end{array}$ \\
\hline \multicolumn{5}{|l|}{ HPA-axis dysregulation } \\
\hline Nelson et al. 1997 [110] & 662 & $617^{1}$ & - & MD more DST non-suppression than AD \\
\hline Anisman et al. 1999 [123] & 17 & 31 & 27 & AD lower cortisol than $C$ \\
\hline Wong et al. 2000 [129] & 10 & - & 14 & MD higher cortisol than $C$ \\
\hline Kaestner et al. 2005 [124] & 21 & $16^{1}$ & 37 & MD higher cortisol than $A D+C$ \\
\hline Lamers et al. 2012 [127] & 66 & 82 & 393 & MD higher cortisol than $A D+C$ \\
\hline Karlovic et al. 2012 [128] & 32 & 23 & 18 & MD higher cortisol than $A D+C$ \\
\hline
\end{tabular}

${ }^{1}$ Atypical depression was assessed as the absence of melancholic depression (non-melancholic depression).

AD, Atypical depression; C, Healthy controls; CRP, C-reactive protein; DST, Dexamethasone suppression test; IL, Interleukin; MD, Melancholic depression; MetS, Metabolic syndrome; TNF, Tumor necrosis factor.

In addition, some studies confirmed higher inflammation levels among atypical depression (see Table 3). Kaestner et al. [124] observed higher levels of IL-1 $\beta$ and IL-1RA in non-melancholic patients than in melancholics and controls. Also Yoon et al. [126] found higher IL-2 and lower IL-4 in atypical depression than in melancholic depression. On the contrary, other studies found higher IL-1 $\beta$ in persons with melancholic features than in those without, or found no inflammation differences between melancholic and atypical depression groups $[123,125,128]$. The largest study to date recently compared 111 chronic melancholic depressed cases versus 122 chronic atypical depressed cases and confirmed higher levels of IL-6, TNF- $\alpha$ and CRP in atypical depression as compared to both melancholic depression and healthy controls [127]. Overall, evidence seems to be emerging that metabolic and, to some extent also, inflammation dysregulations are more advanced in atypical than in melancholic depressed subjects.

The picture is quite different for hypercortisolemia. Table 3 illustrates that several studies directly comparing cortisol levels across melancholic and atypical depression point out that hypercortisolemia is more often observed in melancholic depression [124,127-129]. Cortisol levels among individuals with atypical depression may not be reliably higher than cortisol levels among healthy non- depressed persons. Some studies [123,127] even suggest a relative hypocortisolism in atypical depression. Findings in Table 3 are in line with a sub-analysis in Stetler and Miller's meta-analysis [63] in which the effect size of the cortisol-depression association is higher when more melancholic depressed cases were included in studies, and lower when more atypical depressed cases were included. Melancholic features were associated with 54\% larger effect sizes compared with depression without melancholic features.

Although some studies suggested differences in autonomic tone dysregulation depending on specific depression symptoms $[61,130,131]$, no studies directly compared autonomic tone dysregulation between melancholic versus atypical depression. In all, research into the specificity of the association of biological dysregulations to specific depression subtypes has just begun. Its findings seem to suggest that metabolic and inflammation dysregulations may be more involved in atypical depression, whereas hypercortisolemia appears more specific for melancholic depression. Consequently, not considering the heterogeneity of depression in pathophysiological research may contribute to blurred effect sizes. That metabolic syndrome and potentially also inflammation dysregulations cluster in atypical depression cases is understandable from the tight associations among appetite, fat mass, dyslipidemia and 
inflammation. Weight gain is a cardinal symptom of atypical depression, and a higher BMI has been observed among atypical versus melancholic depressed patients [115]. These mechanisms may not be as strongly related to HPA-axis hyperactivity. Although the HPA-axis in normal situations tempers inflammatory reactions, prolonged hyperactivity could result in blunted anti-inflammatory responses to glucocorticoids resulting in increased inflammation [132,133]. However, the relationship between HPA-activation and its effect on inflammation is extremely complex; whether glucocorticoids increase or decrease inflammation may depend on factors such as dose, duration and timing of glucocorticoids exposure and the brain area involved [134]. Animal models show that GR activation during chronic stress increases lipopolysaccharide (LPS)-induced nuclear factor kappa B (NFkB) activation and TNF- $\alpha$ and IL- $1 \beta$ expression in the hippocampus and frontal cortex, but has opposite effects in the hypothalamus [135]. Furthermore, communication between these systems could also be hampered after prolonged dysregulation of one of the stress systems. This may explain that the HPA-axis and the inflammation/metabolic stress systems operate more independently of each other, and their activities can be differentially linked to different depression subtypes. In line with this, in a cohort of 2,900 subjects, we confirmed strong intercorrelations between the autonomic nervous system and metabolic syndrome indicators but no significant association between these systems with HPA-axis functioning [105].

\section{Therapeutic implications for biological dysregulation in depression}

Do antidepressant treatments reduce biological dysregulations in depression? And if a different pathophysiology exists across depressive subtypes, does this suggest differential effective treatment strategies across subtypes? These are adequate questions that so far have only been partly addressed. We will briefly summarize what is currently known in this research area.

Regarding inflammatory and metabolic dysregulations, an observational cohort study among over 1,000 MDD patients found that, independent of potential differences in severity, TCA users had more metabolic and inflammatory dysregulations than medication-naïve depressed persons $[30,136]$. In contrast, selective serotonin reuptake inhibitor (SSRI) users had slightly lower inflammatory levels than non-medicated depressed patients [136]. Also others found inflammatory and metabolic dysregulations to be more prominent in persons using SNRI, TCA or tetracyclic antidepressants (TeCA) $[39,137]$, whereas beneficial inflammatory profiles were present in SSRI users [106]. In line with this, two metaanalyses showed that SSRI treatment, but not other types of antidepressants, reduced inflammatory levels
[138,139]. In vitro studies [140] demonstrate that administration of SSRIs produces anti-inflammatory effects in blood of both people with depression and healthy volunteers through their effects on increasing intracellular cyclic adenosyl monophosphate, serotonin metabolism or direct action on neurogenesis [141]. On the contrary, TCAs could result in slightly more metabolic dysregulation since its antihistaminergic and adrenergic effects may induce weight gain and subsequent dyslipidemia and hypertension $[142,143]$. Also, both longitudinal observational studies $[98,102,104]$ and a meta-analysis [62] observed increased sympathetic activation and reduced parasympathetic activation among TCA users. The anticholinergic effects of TCAs, and potentially also SNRIs, increase circulating norepinephrine levels, also in the sinoatrial node and left ventricle [144], thereby directly affecting contractility and heart rate. In contrast, SSRIs do not exert such an effect but instead reduce the firing rate in the noradrenergic locus coeruleus [145] involved in generating cardiac sympathetic activity [146]. Consequently, the different effects of antidepressant medication classes on cardiac sympathetic effects appear to have a plausible biological basis, and deserve attention in clinical practice as these effects have shown impact on clinically relevant outcomes, such as hypertension [143].

Whether standard antidepressant treatments improve HPA-axis hyperactivity has not been often addressed. Since this hyperactivity has been observed among remitted depressed patients [108], and non-affected offspring of depressed patients [109], it may be more a vulnerability than a state characteristic. Nevertheless, some evidence suggests that at least a subgroup of depressed patients shows improved HPA-axis regulation, for example, as indicated by a decreased DEX-CRH test response, after a two-week antidepressant treatment period which was subsequently associated with beneficial treatment response [147].

Not only can antidepressants impact on biological dysregulation, dysregulation can also impact on the efficacy of antidepressants. A few recent studies provide evidence for this. A study of $24 \mathrm{MDD}$ inpatients showed that higher IL-6 levels predict non-response to a six-week treatment with amitriptyline, while TNF- $\alpha$ levels were high in both responders and non-responders, but only decreased during treatment in responders [148]. In another study among 100 depressed patients, higher TNF- $\alpha$ levels predicted non-response to a 12-week treatment with escitalopram [149]. Poor treatment response could be the result of inflammatory and metabolic dysregulation having direct negative effects on the monoamine system, such as increasing the activity of monoamine transporters [150] and reducing monoamine precursors [151] and monoamine biosynthesis, [152] which counterbalance effects of antidepressant medication. 
What about other than antidepressant medication interventions? Some recent evidence suggests that add-on anti-inflammatory agents may be useful in clinical depression management. In a placebo-controlled trial of 60 treatment-resistant MDD patients, Raison et al. [153] found a TNF- $\alpha$ antagonist to reduce depressive symptoms in persons with high baseline inflammatory markers. Furthermore, behavioral interventions, such as exercise, were able to normalize immune and metabolic dysregulation [154] and improve mood to some degree [155], and might, therefore, be an indicated treatment especially for the depressed subgroup with inflammatory and metabolic dysregulation. This idea is supported by a recent study showing that exercise treatment appeared to be more effective in reducing depressive symptoms among patients with high baseline levels of TNF- $\alpha$ [156]. However, at this moment, these considerations for treatment implications are still largely speculative and should be confirmed in longitudinal and experimental studies. A recent study did not find larger efficacy of SSRIs or TCAs in melancholic versus atypical depression [157]. Since this review illustrated more metabolic and, although less consistently, inflammatory dysregulations in atypical depression, it should be explored whether, for example, add-on anti-inflammatory agents or alternative treatment regimen, such as exercise, are more beneficial to this depression subgroup.

\section{Conclusions}

This review summarized longitudinal evidence indicating that depression increased the onset risk of a multitude of somatic disorders including, for example, cardiovascular, stroke, diabetes and obesity morbidity. These somatic consequences may partly be due to biological dysregulation present among depressed patients. Less consistent observations are for autonomic dysregulation among depressed patients. However, metabolic dysregulation involving mainly abdominal obesity and dyslipidemia, and potentially also inflammatory dysregulation, appear more often present among depressed persons, especially among those with atypical depression features. Hyperactivity of the HPA-axis has also been observed, but most consistently among depressed patients with melancholic features. These observations suggest that not considering the heterogeneity of depression in pathophysiological research may contribute to blurred effect sizes. Consequently, pathophysiological distinction across depressive subtypes deserves further attention in future research. In addition, other recently indicated physiological mechanisms that could underlie the link between depression and somatic morbidity, such as the oxidative and nitrosative stress (O\&NS) pathways [86], deserve further research. Future research needs to examine to which extent existing and new antidepressant interventions can reduce biological dysregulation thereby improving the vicious cycle in which depression and somatic ill-health interact.

\section{Abbreviations}

ACTH: Adrenocorticotropin hormone; BMI: Body mass index;

$\mathrm{CRH}$ : Corticotropin-releasing hormone; CRP: C-reactive protein; DEX$\mathrm{CRH}$ : Dexamethasone-Corticotropin-releasing hormone; DSM: Diagnostic and statistical manual of mental disorders; GR: Glucocorticoid receptor; HDL: High-density lipoprotein; HPA: Hypothalamic-pituitary-adrenal; HRV: Heart rate variability; IDO: Indoleamine-2,3-dioxygenase; IKK $\beta$ / NFk $\beta$ : Inhibitor of kB kinase- $\beta /$ nuclear factor-k $\beta$; IL: Interleukin;

LPS: Lipopolysaccharide; MDD: Major depressive disorder;

MR: Mineralocorticoid receptor; O\&NS: Oxidative and nitrosative stress; OR: Odds ratio; PEP: Pre-ejection period; RR: Relative risk; SNRI: Serotonergicnoradrenergic reuptake inhibitor; SOCS-3: Suppressor of cytokine signaling-3; SSRI: Selective serotonin reuptake inhibitor; TCA: Tricyclic antidepressant; TeCA: Tetracyclic antidepressant; TNF: Tumor necrosis factor;

TRYCATs: Tryptophan catabolites.

\section{Competing interests}

The authors have no competing interests to report.

\section{Authors' contributions}

BP initiated the paper. BP, YM, FL and NV helped in drafting the paper. BP, YM, FL and NV have seen and approved the final version.

\section{Acknowledgements}

Penninx was supported through a VICl grant (NWO grant 91811602), Lamers was supported through an Intramural Research Training Award from the National Institute of Mental Health, and Vogelzangs was supported through a fellowship from the VU University Medical Center EMGO Institute for Health and Care Research.

\section{Author details}

${ }^{1}$ Department of Psychiatry, EMGO+ Institute and Neuroscience Campus Amsterdam, VU University Medical Center, Amsterdam, The Netherlands. ${ }^{2}$ Genetic Epidemiology Research Branch, National Institute of Mental Health, Bethesda, MD, USA. ${ }^{3}$ Department of Psychiatry, VU University Medical Center and GGZinGeest, AJ Ernststraat 1187, 1081 HL, Amsterdam, The Netherlands.

Received: 14 November 2012 Accepted: 17 April 2013

Published: 15 May 2013

\section{References}

1. Alonso J, Angermeyer MC, Bernert S, Bruffaerts R, Brugha TS, Bryson H, de Girolamo G, Graaf R, Demyttenaere K, Gasquet I, Haro JM, Katz SJ, Kessler RC, Kovess V, Lépine JP, Ormel J, Polidori G, Russo LJ, Vilagut G, Almansa J, Arbabzadeh-Bouchez S, Autonell J, Bernal M, Buist-Bouwman MA, Codony M, Domingo-Salvany A, Ferrer M, Joo SS, Martínez-Alonso M, Matschinger H, et al: Prevalence of mental disorders in Europe: results from the European Study of the Epidemiology of Mental Disorders (ESEMeD) project. Acta Psychiatr Scand Suppl 2004:21-27.

2. Mathers CD, Loncar D: Projections of global mortality and burden of disease from 2002 to 2030. PLoS Med 2006, 3:e442.

3. Nicholson A, Kuper $\mathrm{H}$, Hemingway $\mathrm{H}$ : Depression as an aetiologic and prognostic factor in coronary heart disease: a meta-analysis of 6362 events among 146538 participants in 54 observational studies. Eur Heart J 2006, 27:2763-2774.

4. Mezuk B, Eaton WW, Albrecht S, Golden SH: Depression and type 2 diabetes over the lifespan: a meta-analysis. Diabetes Care 2008, 31:2383-2390.

5. Cuijpers P, Vogelzangs N, Twisk J, Kleiboer A, Li J, Penninx BW: Differential mortality rates in major and subthreshold depression: a meta-analysis of studies that measured both. Br J Psychiatry 2013, 202:22-27.

6. Bogers RP, Bemelmans WJE, Hoogenveen RT, Boshuizen HC, Woodward M, Knekt P, van Dam RM, Hu FB, Visscher TL, Menotti A, Thorpe RJ Jr, Jamrozik K, Calling S, Strand BH, Shipley MJ, BMI-CHD Collaboration Investigators: Association of overweight with increased risk of coronary heart disease partly independent of blood pressure and cholesterol levels: a metaanalysis of 21 cohort studies including more than 300000 persons. Arch Intern Med 2007, 167:1720-1728. 
7. Mottillo S, Filion KB, Genest J, Joseph L, Pilote L, Poirier P, Rinfret S, Schiffrin EL, Eisenberg MJ: The metabolic syndrome and cardiovascular risk a systematic review and meta-analysis. J Am Coll Cardiol 2010, 56:1113-1132.

8. Huxley RR, Barzi F, Lam TH, Czernichow S, Fang X, Welborn T, Shaw J, Ueshima H, Zimmet P, Jee SH, Patel JV, Caterson I, Perkovic V, Woodward M, Asia Pacific Cohort Studies Collaboration and the Obesity in Asia Collaboration: Isolated low levels of high-density lipoprotein cholesterol are associated with an increased risk of coronary heart disease: an individual participant data meta-analysis of 23 studies in the Asia-Pacific region. Circulation 2011, 124:2056-2064.

9. Buckley DI, Fu R, Freeman M, Rogers K, Helfand M: C-reactive protein as a risk factor for coronary heart disease: a systematic review and metaanalyses for the U.S. Preventive Services Task Force. Ann Intern Med 2009, 151:483-495.

10. Vos T, Flaxman AD, Naghavi M, Lozano R, Michaud C, Ezzati M, Shibuya K, Salomon JA, Abdalla S, Aboyans V, Abraham J, Ackerman I, Aggarwal R, Ahn SY, Ali MK, Alvarado M, Anderson HR, Anderson LM, Andrews KG, Atkinson C, Baddour LM, Bahalim AN, Barker-Collo S, Barrero LH, Bartels DH, Basáñez MG, Baxter A, Bell ML, Benjamin EJ, Bennett D, et al: Years lived with disability (YLDs) for 1160 sequelae of 289 diseases and injuries 19902010: a systematic analysis for the Global Burden of Disease Study 2010. Lancet 2012, 380:2163-2196.

11. Murray CJ, Vos T, Lozano R, Naghavi M, Flaxman AD, Michaud C, Ezzati M, Shibuya K, Salomon JA, Abdalla S, Aboyans V, Abraham J, Ackerman I, Aggarwal R, Ahn SY, Ali MK, Alvarado M, Anderson HR, Anderson LM, Andrews KG, Atkinson C, Baddour LM, Bahalim AN, Barker-Collo S, Barrero LH, Bartels DH, Basáñez MG, Baxter A, Bell ML, Benjamin EJ, et al: Disabilityadjusted life years (DALYs) for 291 diseases and injuries in 21 regions, 1990-2010: a systematic analysis for the Global Burden of Disease Study 2010. Lancet 2012, 380:2197-2223.

12. Meng $L$, Chen D, Yang $Y$, Zheng $Y$, Hui R: Depression increases the risk of hypertension incidence: a meta-analysis of prospective cohort studies. J Hypertens 2012, 30:842-851.

13. Dong JY, Zhang YH, Tong J, Qin LQ: Depression and risk of stroke: a meta-analysis of prospective studies. Stroke 2012, 43:32-37.

14. Gao Y, Huang C, Zhao K, Ma L, Qiu X, Zhang L, Xiu Y, Chen L, Lu W, Huang C, Tang $Y$, Xiao Q: Depression as a risk factor for dementia and mild cognitive impairment: a meta-analysis of longitudinal studies. Int $J$ Geriatr Psychiatry 2013, 28:441-449.

15. Luppino FS, van Reedt Dortland AK, Wardenaar KJ, Bouvy PF, Giltay EJ, Zitman FG, Penninx BW: Symptom dimensions of depression and anxiety and the metabolic syndrome. Psychosom Med 2011, 73:257-264.

16. Chida Y, Hamer M, Wardle J, Steptoe A: Do stress-related psychosocial factors contribute to cancer incidence and survival? Nat Clin Pract Oncol 2008, 5:466-475

17. van Gool CH, Kempen Gl, Bosma H, van Boxtel MP, Jolles J, van Eijk JT: Associations between lifestyle and depressed mood: longitudinal results from the Maastricht Aging Study. Am J Public Health 2007, 97:887-894.

18. DiMatteo MR, Lepper HS, Croghan TW: Depression is a risk factor for noncompliance with medical treatment: meta-analysis of the effects of anxiety and depression on patient adherence. Arch Intern Med 2000, 160:2101-2107.

19. Esposito K, Chiodini P, Colao A, Lenzi A, Giugliano D: Metabolic syndrome and risk of cancer: a systematic review and meta-analysis. Diabetes Care 2012, 35:2402-2411.

20. Profenno LA, Porsteinsson AP, Faraone SV: Meta-analysis of Alzheimer's disease risk with obesity, diabetes, and related disorders. Biol Psychiatry 2010, 67:505-512.

21. Eckel RH, Grundy SM, Zimmet PZ: The metabolic syndrome. Lancet 2005, 365:1415-1428.

22. Pan A, Keum N, Okereke Ol, Sun Q, Kivimaki M, Rubin RR, Hu FB. Bidirectional association between depression and metabolic syndrome: a systematic review and meta-analysis of epidemiological studies. Diabetes Care 2012, 35:1171-1180.

23. Foley DL, Morley KI, Madden PA, Heath AC, Whitfield JB, Martin NG: Major depression and the metabolic syndrome. Twin Res Hum Genet 2010, 13:347-358

24. Hildrum B, Mykletun A, Midthjell K, Ismail K, Dahl AA: No association of depression and anxiety with the metabolic syndrome: the Norwegian HUNT study. Acta Psychiatr Scand 2009, 120:14-22
25. Kahl KG, Greggersen W, Schweiger U, Cordes J, Balijepalli C, Lösch C, Moebus S: Prevalence of the metabolic syndrome in unipolar major depression. Eur Arch Psychiatry Clin Neurosci 2012, 262:313-320.

26. Koponen H, Jokelainen J, Keinanen-Kiukaanniemi S, Kumpusalo E, Vanhala M: Metabolic syndrome predisposes to depressive symptoms: a populationbased 7-year follow-up study. J Clin Psychiatry 2008, 69:178-182.

27. Miettola J, Niskanen LK, Viinamaki H, Kumpusalo E: Metabolic syndrome is associated with self-perceived depression. Scand J Prim Health Care 2008, 26:203-210

28. Muhtz C, Zyriax BC, Klahn T, Windler E, Otte C: Depressive symptoms and metabolic risk: effects of cortisol and gender. Psychoneuroendocrinology 2009, 34:1004-1011.

29. Skilton MR, Moulin P, Terra JL, Bonnet F: Associations between anxiety, depression, and the metabolic syndrome. Biol Psychiatry 2007, 62:1251-1257.

30. van Reedt Dortland AK, Giltay EJ, van Veen T, Zitman FG, Penninx BW: Metabolic syndrome abnormalities are associated with severity of anxiety and depression and with tricyclic antidepressant use. Acta Psychiatr Scand 2010, 122:30-39.

31. Vogelzangs N, Suthers K, Ferrucci L, Simonsick EM, Ble A, Schrager M, Bandinelli S, Lauretani F, Giannelli SV, Penninx BW: Hypercortisolemic depression is associated with the metabolic syndrome in late-life. Psychoneuroendocrinology 2007, 32:151-159.

32. Vogelzangs N, Beekman AT, Kritchevsky SB, Newman AB, Pahor M, Yaffe K, Rubin SM, Harris TB, Satterfield S, Simonsick EM, Penninx BW: Psychosocial risk factors and the metabolic syndrome in elderly persons: findings from the health, aging and body composition study. J Gerontol A Biol SCi Med Sci 2007, 62:563-569.

33. Vogelzangs N, Beekman AT, Boelhouwer IG, Bandinelli S, Milaneschi Y, Ferrucci L, Penninx BW: Metabolic depression: a chronic depressive subtype? Findings from the InCHIANTI study of older persons. J Clin Psychiatry 2011, 72:598-604.

34. Akbaraly TN, Ancelin ML, Jaussent I, Ritchie C, Barberger-Gateau P, Dufouil C, Kivimaki M, Berr C, Ritchie K: Metabolic syndrome and onset of depressive symptoms in the elderly: findings from the three-city study. Diabetes Care 2011, 34:904-909.

35. Bove M, Carnevali L, Cicero AF, Grandi E, Gaddoni M, Noera G, Gaddi AV: Psychosocial factors and metabolic parameters: is there any association in elderly people? The Massa Lombarda Project. Aging Ment Health 2010, 14:801-806

36. Dunbar JA, Reddy P, Davis-Lameloise N, Philpot B, Laatikainen T, Kilkkinen A, Bunker SJ, Best JD, Vartiainen E, Kai Lo S, Janus ED: Depression: an important comorbidity with metabolic syndrome in a general population. Diabetes Care 2008, 31:2368-2373

37. Mast BT, Miles T, Penninx BW, Yaffe K, Rosano C, Satterfield S, Ayonayon HN, Harris T, Simonsick EM: Vascular disease and future risk of depressive symptomatology in older adults: findings from the Health, Aging, and Body Composition study. Biol Psychiatry 2008, 64:320-326.

38. Petrlova B, Rosolova H, Hess Z, Podlipny J, Simon J: Depressive disorders and the metabolic syndrome of insulin resistance. Semin Vasc Med 2004, 4:161-165.

39. Pyykkonen AJ, Raikkonen K, Tuomi T, Eriksson JG, Groop L, Isomaa B: Association between depressive symptoms and metabolic syndrome is not explained by antidepressant medication: results from the PPP-Botnia Study. Ann Med 2012, 44:279-288.

40. Veen G, Giltay EJ, DeRijk RH, van Vliet IM, van Pelt J, Zitman FG: Salivary cortisol, serum lipids, and adiposity in patients with depressive and anxiety disorders. Metabolism 2009, 58:821-827.

41. Viscogliosi G, Andreozzi P, Chiriac IM, Cipriani E, Servello A, Marigliano B, Ettorre $\mathrm{E}$, Marigliano V: Depressive symptoms in older people with metabolic syndrome: is there a relationship with inflammation? Int J Geriatr Psychiatry 2013, 28:242-247.

42. Gil K, Radzillowicz P, Zdrojewski T, Pakalska-Korcala A, Chwojnicki K, Piwonski J, Ignaszewska-Wyrzykowska A, Załuga L, Mielczarek M, Landowski J, Wyrzykowski B: Relationship between the prevalence of depressive symptoms and metabolic syndrome. Results of the SOPKARD Project. Kardiol Pol 2006, 64:464-469.

43. Viinamaki $H$, Heiskanen $T$, Lehto SM, Niskanen L, Koivumaa-Honkanen $H_{4}$ Tolmunen T, Honkalampi K, Saharinen T, Haatainen K, Hintikka J: Association of depressive symptoms and metabolic syndrome in men. Acta Psychiatr Scand 2009, 120:23-29. 
44. Pulkki-Råback L, Elovainio M, Kivimäki M, Mattsson N, Raitakari OT, Puttonen S, Marniemi J, Viikari JS, Keltikangas-Järvinen L: Depressive symptoms and the metabolic syndrome in childhood and adulthood: a prospective cohort study. Health Psychol 2009, 28:108-116.

45. Toker S, Shirom A, Melamed S: Depression and the metabolic syndrome: gender-dependent associations. Depress Anxiety 2008, 25:661-669.

46. Vanhala M, Jokelainen J, Keinanen-Kiukaanniemi S, Kumpusalo E, Koponen $\mathrm{H}$ : Depressive symptoms predispose females to metabolic syndrome: a 7-year follow-up study. Acta Psychiatr Scand 2009, 119:137-142.

47. McCaffery JM, Niaura R, Todaro JF, Swan GE, Carmelli D: Depressive symptoms and metabolic risk in adult male twins enrolled in the National Heart, Lung, and Blood Institute twin study. Psychosom Med 2003, 65:490-497.

48. Takeuchi T, Nakao M, Nomura K, Yano E: Association of metabolic syndrome with depression and anxiety in Japanese men. Diabetes Metab 2009, 35:32-36.

49. Takeuchi T, Nakao M, Nomura K, Inoue M, Tsurugano S, Shinozaki Y, Yano E: Association of the metabolic syndrome with depression and anxiety in Japanese men: a 1-year cohort study. Diabetes Metab Res Rev 2009, 25:762-767.

50. Raikkonen K, Matthews KA, Kuller LH: Depressive symptoms and stressful life events predict metabolic syndrome among middle-aged women: a comparison of World Health Organization, Adult Treatment Panel III, and International Diabetes Foundation definitions. Diabetes Care 2007, 30:872-877.

51. Vaccarino V, McClure C, Johnson BD, Sheps DS, Bittner V, Rutledge T, Shaw U, Sopko G, Olson MB, Krantz DS, Parashar S, Marroquin OC, Merz CN: Depression, the metabolic syndrome and cardiovascular risk. Psychosom Med 2008, 70:40-48.

52. Kahl KG: [The metabolic syndrome and mental illness: relevance, risk factors and practical consequences]. MMW Fortschr Med 2005, 147:32-34, 36.

53. Seppälä J, Vanhala M, Kautiainen H, Eriksson J, Kampman O, Mäntyselkä P, Oksa H, Ovaskainen Y, Viikki M, Koponen H: Prevalence of metabolic syndrome in subjects with melancholic and non-melancholic depressive symptoms. A Finnish population-based study. J Affect Disord 2012, 136:543-549.

54. Vogelzangs N, Beekman AT, Dik MG, Bremmer MA, Comijs HC, Hoogendijk WJ, Deeg DJ, Penninx BW: Late-life depression, cortisol, and the metabolic syndrome. Am J Geriatr Psychiatry 2009, 17:716-721.

55. Kinder LS, Carnethon MR, Palaniappan LP, King AC, Fortmann SP: Depression and the metabolic syndrome in young adults: findings from the Third National Health and Nutrition Examination Survey. Psychosom Med 2004, 66:316-322.

56. Raikkonen K, Matthews KA, Kuller LH: The relationship between psychological risk attributes and the metabolic syndrome in healthy women: antecedent or consequence? Metabolism 2002, 51:1573-1577.

57. $\mathrm{Xu} \mathrm{Q}$, Anderson $\mathrm{D}$, Lurie-Beck J: The relationship between abdominal obesity and depression in the general population: A systematic review and meta-analysis. Obes Res Clin Practice 2011, 5:e267-e278.

58. Howren MB, Lamkin DM, Suls J: Associations of depression with C-reactive protein, IL-1, and IL-6: a meta-analysis. Psychosom Med 2009, 71:171-186.

59. Dowlati Y, Herrmann N, Swardfager W, Liu H, Sham L, Reim EK, Lanctôt KL: A meta-analysis of cytokines in major depression. Biol Psychiatry 2010, 67:446-457

60. Liu Y, Ho RC, Mak A: Interleukin (IL)-6, tumour necrosis factor alpha (TNF-alpha) and soluble interleukin-2 receptors (sIL-2R) are elevated in patients with major depressive disorder: a meta-analysis and metaregression. J Affect Disord 2012, 139:230-239.

61. Rottenberg J: Cardiac vagal control in depression: a critical analysis. Biol Psychol 2007, 74:200-211.

62. Kemp AH, Quintana DS, Gray MA, Felmingham KL, Brown K, Gatt JM: Impact of depression and antidepressant treatment on heart rate variability: a review and meta-analysis. Biol Psychiatry 2010, 67:1067-1074.

63. Stetler C, Miller GE: Depression and hypothalamic-pituitary-adrenal activation: a quantitative summary of four decades of research. Psychosom Med 2011, 73:114-126.

64. Knorr U, Vinberg M, Kessing LV, Wetterslev J: Salivary cortisol in depressed patients versus control persons: a systematic review and meta-analysis. Psychoneuroendocrinology 2010, 35:1275-1286.

65. Esteve E, Ricart W, Fernandez-Real JM: Dyslipidemia and inflammation: an evolutionary conserved mechanism. Clin Nutr 2005, 24:16-31.
66. Osborn O, Olefsky JM: The cellular and signaling networks linking the immune system and metabolism in disease. Nat Med 2012, 18:363-374.

67. Zhang X, Zhang G, Zhang H, Karin M, Bai H, Cai D: Hypothalamic IKKbeta/ NF-kappaB and ER stress link overnutrition to energy imbalance and obesity. Cell 2008, 135:61-73

68. Krishnan V, Nestler EJ: Linking molecules to mood: new insight into the biology of depression. Am J Psychiatry 2010, 167:1305-1320.

69. Paz-Filho G, Wong ML, Licinio J: The procognitive effects of leptin in the brain and their clinical implications. Int J Clin Pract 2010, 64:1808-1812.

70. Alexopoulos GS: The vascular depression hypothesis: 10 years later. Biol Psychiatry 2006, 60:1304-1305.

71. Bjorntorp P: Do stress reactions cause abdominal obesity and comorbidities? Obes Rev 2001, 2:73-86.

72. Tentolouris N, Argyrakopoulou G, Katsilambros N: Perturbed autonomic nervous system function in metabolic syndrome. Neuromolecular Med 2008, 10:169-178.

73. Maes M, Bosmans E, Meltzer HY, Scharpe S, Suy E: Interleukin-1 beta: a putative mediator of HPA axis hyperactivity in major depression? Am J Psychiatry 1993, 150:1189-1193.

74. Maes M: A review on the acute phase response in major depression. Rev Neurosci 1993, 4:407-416.

75. Cesari M, Penninx BW, Newman AB, Kritchevsky SB, Nicklas BJ, Sutton-Tyrrell K, Rubin SM, Ding J, Simonsick EM, Harris TB, Pahor M: Inflammatory markers and onset of cardiovascular events: results from the Health $A B C$ study. Circulation 2003, 108:2317-2322.

76. Emerging Risk Factors Collaboration, Kaptoge S, Di Angelantonio E, Lowe G, Pepys MB, Thompson SG, Collins R, Danesh J: C-reactive protein concentration and risk of coronary heart disease, stroke, and mortality: an individual participant meta-analysis. Lancet 2010, 375:132-140.

77. Visser M, Bouter LM, McQuillan GM, Wener MH, Harris TB: Elevated Creactive protein levels in overweight and obese adults. JAMA 1999, 282:2131-2135.

78. Ingelsson E, Hulthe J, Lind L: Inflammatory markers in relation to insulin resistance and the metabolic syndrome. Eur J Clin Invest 2008, 38:502-509.

79. Anisman H, Hayley S, Turrin N, Merali Z: Cytokines as a stressor: implications for depressive illness. Int J Neuropsychopharmacol 2002, 5:357-373

80. Bonaccorso S, Marino V, Puzella A, Pasquini M, Biondi M, Artini M, Almerighi C, Verkerk R, Meltzer H, Maes M: Increased depressive ratings in patients with hepatitis $C$ receiving interferon-alpha-based immunotherapy are related to interferon-alpha-induced changes in the serotonergic system. J Clin Psychopharmacol 2002, 22:86-90.

81. Shelton RC, Miller AH: Eating ourselves to death (and despair): the contribution of adiposity and inflammation to depression. Prog Neurobiol 2010, 91:275-299.

82. Sublette ME, Postolache T: Neuroinflammation and depression: the role of indoleamine 2,3-dioxygenase (IDO) as a molecular pathway. Psychosom Med 2012, 74:668-672.

83. Wichers MC, Koek GH, Robaeys G, Verkerk R, Scharpe S, Maes M: IDO and interferon-alpha-induced depressive symptoms: a shift in hypothesis from tryptophan depletion to neurotoxicity. Mol Psychiatry 2005, 10:538-544.

84. Maes M, Berk M, Goehler L, Song C, Anderson G, Galecki P, Leonard B: Depression and sickness behavior are Janus-faced responses to shared inflammatory pathways. BMC Med 2012, 10:66.

85. Anderson G, Maes M, Berk M: Inflammation-related disorders in the tryptophan catabolite pathway in depression and somatization. Adv Protein Chem Struct Biol 2012, 88:27-48.

86. Maes M, Galecki P, Chang YS, Berk M: A review on the oxidative and nitrosative stress (O\&NS) pathways in major depression and their possible contribution to the (neuro)degenerative processes in that illness. Prog Neuropsychopharmacol Biol Psychiatry 2011, 35:676-692.

87. Maes M, Kubera M, Leunis JC, Berk M: Increased IgA and IgM responses against gut commensals in chronic depression: further evidence for increased bacterial translocation or leaky gut. J Affect Disord 2012, 141:55-62.

88. Schildkraut JJ, Orsulak PJ, Schatzberg AF, Gudeman JE, Cole JO, Rohde WA, LaBrie RA: Toward a biochemical classification of depressive disorders. I. Differences in urinary excretion of MHPG and other catecholamine metabolites in clinically defined subtypes of depressions. Arch Gen Psychiatry 1978, 35:1427-1433. 
89. Linnoila M, Karoum F, Calil HM, Kopin IJ, Potter WZ: Alteration of norepinephrine metabolism with desipramine and zimelidine in depressed patients. Arch Gen Psychiatry 1982, 39:1025-1028.

90. Roy A, Pickar D, Linnoila M, Potter WZ: Plasma norepinephrine level in affective disorders. Relationship to melancholia. Arch Gen Psychiatry 1985, 42:1181-1185.

91. Esler M, Turbott J, Schwarz R, Leonard P, Bobik A, Skews H, Jackman G: The peripheral kinetics of norepinephrine in depressive illness. Arch Gen Psychiatry 1982, 39:295-300.

92. Veith RC, Lewis N, Linares OA, Barnes RF, Raskind MA, Villacres EC, Murburg MM, Ashleigh EA, Castillo S, Peskind ER, et al: Sympathetic nervous system activity in major depression. Basal and desipramineinduced alterations in plasma norepinephrine kinetics. Arch Gen Psychiatry 1994, 51:411-422.

93. Barton DA, Dawood T, Lambert EA, Esler MD, Haikerwal D, Brenchley C, Socratous F, Kaye DM, Schlaich MP, Hickie I, Lambert GW: Sympathetic activity in major depressive disorder: identifying those at increased cardiac risk? J Hypertens 2007, 25:2117-2124.

94. Dekker JM, Crow RS, Folsom AR, Hannan PJ, Liao D, Swenne CA, Schouten EG Low heart rate variability in a 2-minute rhythm strip predicts risk of coronary heart disease and mortality from several causes: the ARIC Study. Atherosclerosis risk in communities. Circulation 2000, 102:1239-1244.

95. Tsuji H, Larson MG, Venditti FJ Jr, Manders ES, Evans JC, Feldman CL, Levy D: Impact of reduced heart rate variability on risk for cardiac events. The Framingham Heart Study. Circulation 1996, 94:2850-2855.

96. Porges SW: The polyvagal theory: phylogenetic substrates of a social nervous system. Int J Psychophysiol 2001, 42:123-146.

97. Licht CM, de Geus EJ, Zitman FG, Hoogendijk WJ, van Dyck R, Penninx BW: Association between major depressive disorder and heart rate variability in the Netherlands Study of Depression and Anxiety (NESDA). Arch Gen Psychiatry 2008, 65:1358-1367.

98. Licht CM, de Geus EJ, van Dyck R, Penninx BW: Longitudinal evidence for unfavorable effects of antidepressants on heart rate variability. Biol Psychiatry 2010, 68:861-868.

99. Light KC, Kothandapani RV, Allen MT: Enhanced cardiovascular and catecholamine responses in women with depressive symptoms. Int $J$ Psychophysiol 1998, 28:157-166.

100. Guinjoan SM, Bernabo JL, Cardinali DP: Cardiovascular tests of autonomic function and sympathetic skin responses in patients with major depression. J Neurol Neurosurg Psychiatry 1995, 59:299-302.

101. Gold PW, Wong ML, Goldstein DS, Gold HK, Ronsaville DS, Esler M, Alesci S, Masood A, Licinio J, Geracioti TD Jr, Perini G, DeBellis MD, Holmes C, Vgontzas AN, Charney DS, Chrousos GP, McCann SM, Kling MA: Cardiac implications of increased arterial entry and reversible 24-h central and peripheral norepinephrine levels in melancholia. Proc Natl Acad Sci USA 2005, 102:8303-8308.

102. Koschke M, Boettger MK, Schulz S, Berger S, Terhaar J, Voss A, Yeragani VK, Bär KJ: Autonomy of autonomic dysfunction in major depression. Psychosom Med 2009, 71:852-860.

103. Ahrens T, Deuschle M, Krumm B, van der Pompe G, den Boer JA, Lederbogen F: Pituitary-adrenal and sympathetic nervous system responses to stress in women remitted from recurrent major depression. Psychosom Med 2008, 70:461-467.

104. Licht CM, Penninx BW, de Geus EJ: Effects of antidepressants, but not psychopathology, on cardiac sympathetic control: a longitudinal study. Neuropsychopharmacology 2012, 37:2487-2495.

105. Licht CM, Vreeburg SA, van Reedt Dortland AK, Giltay EJ, Hoogendijk WJ, DeRijk RH, Vogelzangs N, Zitman FG, de Geus EJ, Penninx BW: Increased sympathetic and decreased parasympathetic activity rather than changes in hypothalamic-pituitary-adrenal axis activity is associated with metabolic abnormalities. J Clin Endocrinol Metab 2010, 95:2458-2466.

106. Miller AH, Maletic V, Raison CL: Inflammation and its discontents: the role of cytokines in the pathophysiology of major depression. Biol Psychiatry 2009, 65:732-741.

107. Belmaker RH, Agam G: Major depressive disorder. N Engl J Med 2008, 358:55-68.

108. Vreeburg SA, Hoogendijk WJ, van Pelt J, Derijk RH, Verhagen JC, van Dyck R, Smit JH, Zitman FG, Penninx BW: Major depressive disorder and hypothalamic-pituitary-adrenal axis activity: results from a large cohort study. Arch Gen Psychiatry 2009, 66:617-626.
109. Vreeburg SA, Hartman CA, Hoogendijk WJ, van Dyck R, Zitman FG, Ormel J, Penninx BW: Parental history of depression or anxiety and the cortisol awakening response. Br J Psychiatry 2010, 197:180-185.

110. Nelson JC, Davis JM: DST studies in psychotic depression: a meta-analysis. Am J Psychiatry 1997, 154:1497-1503.

111. de Kloet ER, Joels M, Holsboer F: Stress and the brain: from adaptation to disease. Nat Rev Neurosci 2005, 6:463-475.

112. Silverman MN, Sternberg EM: Glucocorticoid regulation of inflammation and its functional correlates: from HPA axis to glucocorticoid receptor dysfunction. Ann N Y Acad Sci 2012, 1261:55-63.

113. Pace TW, Miller AH: Cytokines and glucocorticoid receptor signaling. Relevance to major depression. Ann N Y Acad Sci 2009, 1179:86-105.

114. Major Depressive Disorder Working Group of the Psychiatric GWAS Consortium, Ripke S, Wray NR, Lewis CM, Hamilton SP, Weissman MM, Breen G, Byrne EM, Blackwood DH, Boomsma DI, Cichon S, Heath AC, Holsboer F, Lucae S, Madden PA, Martin NG, McGuffin P, Muglia P, Noethen MM, Penninx BP, Pergadia ML, Potash JB, Rietschel M, Lin D, Müller-Myhsok B, Shi J, Steinberg S, Grabe HJ, Lichtenstein P, Magnusson P, Perlis RH, et al: A mega-analysis of genome-wide association studies for major depressive disorder. Mol Psychiatry 2013, 18:497-511.

115. Lamers F, De Jonge P, Nolen WA, Smit JH, Zitman FG, Beekman AT, Penninx BW: Identifying depressive subtypes in a large cohort study: results from the Netherlands Study of Depression and Anxiety (NESDA). J Clin Psychiatry 2010, 71:1582-1589.

116. Lamers F, Burstein M, He J, Avenevoli S, Angst J, Merikangas KR: Structure of major depressive disorder in adolescents and adults in the US general population. Br J Psychiatry 2012, 201:143-150.

117. Angst J, Gamma A, Benazzi F, Silverstein B, Ajdacic-Gross V, Eich D, Rössler W: Atypical depressive syndromes in varying definitions. Eur Arch Psychiatry Clin Neurosci 2006, 256:44-54.

118. Williamson DE, Birmaher B, Brent DA, Balach L, Dahl RE, Ryan ND: Atypical symptoms of depression in a sample of depressed child and adolescent outpatients. J Am Acad Child Adolesc Psychiatry 2000, 39:1253-1259.

119. Angst J, Gamma A, Sellaro R, Zhang H, Merikangas K: Toward validation of atypical depression in the community: results of the Zurich cohort study. $J$ Affect Disord 2002, 72:125-138.

120. Sullivan PF, Kessler RC, Kendler KS: Latent class analysis of lifetime depressive symptoms in the national comorbidity survey. Am J Psychiatry 1998, 155:1398-1406.

121. Sullivan PF, Prescott CA, Kendler KS: The subtypes of major depression in a twin registry. J Affect Disord 2002, 68:273-284.

122. Kendler KS, Eaves LJ, Walters EE, Neale MC, Heath AC, Kessler RC: The identification and validation of distinct depressive syndromes in a population-based sample of female twins. Arch Gen Psychiatry 1996, 53:391-399.

123. Anisman H, Ravindran AV, Griffiths J, Merali Z: Endocrine and cytokine correlates of major depression and dysthymia with typical or atypical features. Mol Psychiatry 1999, 4:182-188.

124. Kaestner F, Hettich M, Peters M, Sibrowski W, Hetzel G, Ponath G, Arolt V, Cassens $U$, Rothermundt M: Different activation patterns of proinflammatory cytokines in melancholic and non-melancholic major depression are associated with HPA axis activity. J Affect Disord 2005, 87:305-311.

125. Huang $T L$, Lee $C T$ : T-helper $1 / T$-helper 2 cytokine imbalance and clinical phenotypes of acute-phase major depression. Psychiatry Clin Neurosci 2007, 61:415-420.

126. Yoon HK, Kim YK, Lee HJ, Kwon DY, Kim L: Role of cytokines in atypical depression. Nord J Psychiatry 2012, 66:183-188.

127. Lamers F, Vogelzangs N, Merikangas KR, de Jonge P, Beekman AT, Penninx BW: Evidence for a differential role of HPA-axis function, inflammation and metabolic syndrome in melancholic versus atypical depression. Mol Psychiatry 2012 [Epub ahead of print.].

128. Karlovic D, Serretti A, Vrkic N, Martinac M, Marcinko D: Serum concentrations of CRP, IL-6, TNF-alpha and cortisol in major depressive disorder with melancholic or atypical features. Psychiatry Res 2013, 47:162-167.

129. Wong ML, Kling MA, Munson PJ, Listwak S, Licinio J, Prolo P, Karp B, McCutcheon IE, Geracioti TD Jr, DeBellis MD, Rice KC, Goldstein DS, Veldhuis JD, Chrousos GP, Oldfield EH, McCann SM, Gold PW: Pronounced and sustained central hypernoradrenergic function in major depression with melancholic features: relation to hypercortisolism and corticotropinreleasing hormone. Proc Natl Acad Sci USA 2000, 97:325-330. 
130. De Jonge $P$, Mangano D, Whooley MA: Differential association of cognitive and somatic depressive symptoms with heart rate variability in patients with stable coronary heart disease: findings from the Heart and Soul Study. Psychosom Med 2007, 69:735-739.

131. Rottenberg J, Chambers AS, Allen JJ, Manber R: Cardiac vagal control in the severity and course of depression: the importance of symptomatic heterogeneity. J Affect Disord 2007, 103:173-179.

132. Miller GE, Cohen S, Ritchey AK: Chronic psychological stress and the regulation of pro-inflammatory cytokines: a glucocorticoid-resistance model. Health Psychol 2002, 21:531-541.

133. Wirtz PH, von Kanel R, Schnorpfeil P, Ehlert U, Frey K, Fischer JE: Reduced glucocorticoid sensitivity of monocyte interleukin- 6 production in male industrial employees who are vitally exhausted. Psychosom Med 2003, 65:672-678.

134. Sorrells SF, Caso JR, Munhoz CD, Sapolsky RM: The stressed CNS: when glucocorticoids aggravate inflammation. Neuron 2009, 64:33-39.

135. Munhoz CD, Lepsch LB, Kawamoto EM, Malta MB, Lima Lde S, Avellar MC, Sapolsky RM, Scavone C: Chronic unpredictable stress exacerbates lipopolysaccharide-induced activation of nuclear factor-kappaB in the frontal cortex and hippocampus via glucocorticoid secretion. J Neurosci 2006, 26:3813-3820

136. Vogelzangs N, Duivis HE, Beekman AT, Kluft C, Neuteboom J, Hoogendijk W, Smit JH, de Jonge P, Penninx BW: Association of depressive disorders, depression characteristics and antidepressant medication with inflammation. Trans/ Psychiatry 2012, 2:e79.

137. Hamer M, Batty GD, Marmot MG, Singh-Manoux A, Kivimaki M: Antidepressant medication use and C-reactive protein: results from two population-based studies. Brain Behav Immun 2011, 25:168-173.

138. Hannestad J, DellaGioia N, Bloch M: The effect of antidepressant medication treatment on serum levels of inflammatory cytokines: a meta-analysis. Neuropsychopharmacology 2011, 36:2452-2459.

139. Hiles S, Baker A, de Malmanche T, Attia J: Interleukin-6, C-reactive protein and interleukin-10 after antidepressant treatment in people with depression: a meta-analysis. Psychol Med 2012, 42:2015-2026.

140. Kenis G, Maes M: Effects of antidepressants on the production of cytokines. Int I Neuropsychopharmacol 2002, 5:401-412.

141. Janssen DG, Caniato RN, Verster JC, Baune BT: A psychoneuroimmunological review on cytokines involved in antidepressant treatment response. Hum Psychopharmacol 2010, 25:201-215.

142. Fava M: Weight gain and antidepressants. J Clin Psychiatry 2000, 61:37-41.

143. Licht CM, de Geus EJ, Seldenrijk A, van Hout HP, Zitman FG, van Dyck R, Penninx BW: Depression is associated with decreased blood pressure, but antidepressant use increases the risk for hypertension. Hypertension 2009, 53:631-638.

144. Shimizu S, Akiyama T, Kawada T, Shishido T, Mizuno M, Kamiya A, Yamazaki T, Sano S, Sugimachi M: In vivo direct monitoring of interstitial norepinephrine levels at the sinoatrial node. Auton Neurosci 2010, 152:115-118.

145. Grant MM, Weiss JM: Effects of chronic antidepressant drug administration and electroconvulsive shock on locus coeruleus electrophysiologic activity. Biol Psychiatry 2001, 49:117-129.

146. Elam M, Thoren P, Svensson TH: Locus coeruleus neurons and sympathetic nerves: activation by visceral afferents. Brain Res 1986, 375:117-125.

147. Ising M, Horstmann S, Kloiber S, Lucae S, Binder EB, Kern N, Künzel HE, Pfennig A, Uhr M, Holsboer F: Combined dexamethasone/corticotropin releasing hormone test predicts treatment response in major depression - a potential biomarker? Biol Psychiatry 2007, 62:47-54

148. Lanquillon S, Krieg JC, Bening-Abu-Shach U, Vedder H: Cytokine production and treatment response in major depressive disorder. Neuropsychopharmacology 2000, 22:370-379.

149. Eller T, Vasar V, Shlik J, Maron E: Pro-inflammatory cytokines and treatment response to escitalopram in major depressive disorder. Prog Neuropsychopharmacol Biol Psychiatry 2008, 32:445-450.

150. Zhu CB, Blakely RD, Hewlett WA: The proinflammatory cytokines interleukin-1 beta and tumor necrosis factor-alpha activate serotonin transporters. Neuropsychopharmacology 2006, 31:2121-2131.

151. Widner B, Laich A, Sperner-Unterweger B, Ledochowski M, Fuchs D: Neopterin production, tryptophan degradation, and mental depressionwhat is the link? Brain Behav Immun 2002, 16:590-595.
152. Neurauter G, Schröcksnadel K, Scholl-Bürgi S, Sperner-Unterweger B, Schubert C, Ledochowski M, Fuchs D: Chronic immune stimulation correlates with reduced phenylalanine turnover. Curr Drug Metab 2008, 9:622-627.

153. Raison CL, Rutherford RE, Woolwine BJ, Shuo C, Schettler P, Drake DF, Haroon E, Miller AH: A randomized controlled trial of the tumor necrosis factor antagonist infliximab for treatment-resistant depression: the role of baseline inflammatory biomarkers. JAMA Psychiatry 2013, 70:31-41.

154. You T, Nicklas BJ: Effects of exercise on adipokines and the metabolic syndrome. Curr Diab Rep 2008, 8:7-11.

155. Mead GE, Morley W, Campbell P, Greig CA, McMurdo M, Lawlor DA: Exercise for depression. Cochrane Database Syst Rev 2009:CD004366.

156. Rethorst C, Toups M, Greer T, Nakonezny P, Carmody T, Grannemann B, Huebinger RM, Barber RC, Trivedi MH: Pro-inflammatory cytokines as predictors of antidepressant effects of exercise in major depressive disorder. Mol Psychiatry 2012 [Epub ahead of print.].

157. Uher R, Dernovsek MZ, Mors O, Hauser J, Souery D, Zobel A, Maier W, Henigsberg N, Kalember P, Rietschel M, Placentino A, Mendlewicz J, Aitchison KJ, McGuffin P, Farmer A: Melancholic, atypical and anxious depression subtypes and outcome of treatment with escitalopram and nortriptyline. J Affect Disord 2011, 132:112-120.

\section{doi:10.1186/1741-7015-11-129}

Cite this article as: Penninx et al:: Understanding the somatic

consequences of depression: biological mechanisms and the role of depression symptom profile. BMC Medicine 2013 11:129.

\section{Submit your next manuscript to BioMed Central and take full advantage of:}

- Convenient online submission

- Thorough peer review

- No space constraints or color figure charges

- Immediate publication on acceptance

- Inclusion in PubMed, CAS, Scopus and Google Scholar

- Research which is freely available for redistribution

Submit your manuscript at www.biomedcentral.com/submit
C) Biomed Central 